ground from the shut-down core. Fuel handling is carried out by means of a simple hand-operated tool under direct visual control.

Table 1 lists the main reactor parameters and Table 2 summarizes the fluxes available in the experimental facilities.

It is expected that about 75 per cent of the reactor operating time will be allotted to research and the remainder to postgraduate and undergraduate teaching. The initial demand for experimental time for research has been heavier than expected. About fifteen proposals have already been authorized by the Reactor Safety Committee and nearly half of these are large-scale experiments requiring prolonged use of the reactor. Two short experiments were completed during the commissioning period. So far, the majority of the experiments have been put forward by Imperial College staff, who have been in closer contact with reactor progress than other potential users, but general demand is expected to grow rapidly now that routine operation has begun. It is clear that the reactor is meeting a real need, and we look forward to a long and useful operating life.

\title{
OBITUARIES
}

\section{Sir John Gaddum, F.R.S.}

The death, on June 30, 1965, of Sir John Gaddum has deprived physiology and pharmacology of one of their leading personalities. He died after a long illness, uncomplainingly borne, at his home in Cambridge at the age of sixty-five. Born in Bowdon, Cheshire, he was educated at Rugby and at Trinity College, Cambridge. There he read mathematics and, in his last two years, physiology as part of the Natural Sciences Tripos. It was later a source of merriment to him and of solace to his fellow sufferers that he only gained a 'second class' in physiology. From Cambridge he went to University College Hospital, London, where he obtained his medical qualifications in 1925. For the next two years he worked with J. W. Trevan at the Wellcome Physiological Research Laboratories in Beckenham.

Gaddum's first paper there on the antagonism of adrenaline and ergotamine on the uterus of the rabbit was an indicator of things to come: his interest in drug antagonism, his mathematical treatment of biological datr, the use of smooth muscle as a convenient quantitative measure of drug action, were indicative of much of his later work. The years 1927-34 were spent at the National Institute for Medical Research, Hampstead, under the directorship of H. H. (now Sir Henry) Dale. Many of the papers of these years are exercises in quantitative pharmacology and have helped to lay the foundation of accurate measurement of drug effects, and of estimation of errors due to sampling and other sources. He introduced the 'normal equivalent deviation' in the evaluation of quantal assays. He devised or improved the biological assay of substances which occurred in tissues in such small quantities that their chemical determination was impossible. There was also the discovery, with U. S. v. Euler, of a biologically active polypeptide in tissues ('substance $P$ '), and with H. Schild, of a fluorimetric test for adrenaline. However, the investigation he most enjoyed during this period was one which led to the discovery, with W. Feldberg, that acetylcholine was the chemical transmitter at preganglionic autonomic synapses.

During his stay at Hampstead, Gaddum married a former fellow student, Dr. Iris Mary Harmer, with whom he shared many interests during their long married life, and who now survives him. They had three daughters, all of whom are married.

During 1934-58 Gaddurn held chairs in pharmacology in the University of Cairo, University College, London, the College of the Pharmaceutical Society of Great Britain, and Edinburgh. Here he succeeded A. J. Clark in 1942 after several war years spent in work for the Ministry of Supply, to which he remained an adviser for many years to come. The release of histamine, the nature of the transmitter at adrenergic nerve endings, the role of 5-hydroxytryptamine in brain activity, and the assay of bradykinin were among his interests in the Edinburgh years. In two papers he drew attention to the fact that many biological phenomena exhibit a lognormal distribution. He greatly improved the specificity of bio logical assays. This was done either by the use of specific antagonists, if necessary by desensitizing the tissue with a large dose of the substance the presence of which was suspected; or unambiguous clues to the identity of the unknown material were obtained by measuring its effect on many organs in parallel and estimating its potencies in relation to known reference substances. To the end of his life, Gaddum worked on active substances extractable from tissues, but his interest shifted increasingly to the search for new transmitters in the central nervous system. His last paper, started before he became ill and completed during the years of illness, deals with the chemical and structural requisites of central nervous activity. It is now in the press. In 1958, Gaddum accepted an offer from the Agricultural Research Council to succeed I. de Burgh Daly as director of the Council's Institute of Animal Physiology at Babraham, Cambridge. Always ready for new experience, he took up the challenge of learning about the needs of the physiology of farm animals and travelled all over the world to find out what was done in this field elsewhere. The growth of the Institute during his directorship is a telling tribute to his success.

Gaddum's singular achievements were due to a combination of mathematical ability, technical inventiveness (he constructed many useful research tools, the last one, the 'push-pull cannula', in 1961), with an unflinching interest in all biological, in fact all natural, phenomena, of which physiology and pharmacology were but one section. He had the mind of a naturalist, looking for plants and birds on his travels, and possessed an intellectual curiosity which did not fail him to the end. The capacity to take interest in new disciplines stood him in good stead when he gave up his chair to become director of the Babraham Institute.

During the years that Gaddum held professorships he had pupils from many lands. These will remember not only his brilliant mind but also his complete lack of prejudice, his willingness to hear all views, his integrity and sense of duty, his kindness and modesty, and the way in which a busy man gave freely of his time to their many needs. Gaddum considered it a scientist's duty to encourage international co-operation, and he certainly made an outstanding ambassador of good will.

Among the honours conferred on him was the fellow. ship of the Royal Society in 1945, an honorary LL.D. from the University of Edinburgh in 1964, and a knighthood in the same year.

MARTHE Vogt

\section{Dr. H. J. Gough, C.B., M.B.E., F.R.S.}

AFter a working life devoted to research in engineering at the National Physical Laboratory, the War Office, the Ministry of Supply and Unilever, Ltd., Dr. H. J. Gough for the past ten years had been living in retirement at Rottingdean; but he had maintained his interest in his old pursuits and during his retirement had continued to 